\title{
Developing Organizational Culture In Independently Owned Restaurants: Links To Service Quality And Customers' Intentions To Return
}

\author{
Dean A. Koutroumanis, University of Tampa, USA \\ Mary Anne Watson, University of Tampa, USA \\ Barbara R. Dastoor, Nova Southeastern University, USA
}

\begin{abstract}
The study developed and tested a model of organizational culture and customer service as they relate to behavioral intention to return in independently owned, casual dining restaurants. It adds to previous work on organizational culture and hospitality as they related to service quality and behavioral intentions to return by assessing two types of organizational culture, clan and market types. Results indicate that, as proposed, clan culture type is positively related to high levels of perceived service quality and to intentions to return to the restaurant; however market culture type is, as expected, negatively related to intentions to return. The findings lead to practical applications for the restaurant industry with a blueprint for practitioners to develop and improve their service delivery practices in order to generate a larger number of repeat customers.
\end{abstract}

Keywords: Organizational Culture; Service Quality; Behavioral Intentions; Small Business; Restaurants

\section{INTRODUCTION}

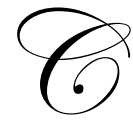

urrent global economic conditions have had a negative financial impact on the restaurant industry (Brandau, 2009). The approach of conducting business as usual is a concept of the past in many industries. The "Great Recession" has had a profound negative effect on the restaurant industry, causing a record number of closures. According to NPD (global research firm), over 4000 (based on US figures only) restaurants have closed for business in a one year period, April 2008 to March 2009. That is a 1\% increase in failure year to year for all restaurants, with independents seeing a $2 \%$ increase in failure rate over the same period (Lockyer, 2009). As the restaurant industry continues to struggle through the turmoil, the complexities of restaurant operations are magnified in scope and context. The US Department of Labor projects an increase of 1.8 million employees in the restaurant industry by the year 2014 (National Restaurant Association, 2010). Globally the hospitality industry as a whole is the third largest segment in the service sector (Collins, 2007). Employee attitudes, behaviors and work effort all play an integral role in the service delivery process (Seidman, 2001), and play an integral role on the development of organizational culture as well. Employee attitudes relate directly to customer satisfaction and customer retention in the service industry (Kattara, Weheba \& El-Said, 2008; Davidson 2003; Schneider \& Bowen, 1993; Stamper \& Van Dyne, 2003).

A 2004 survey of restaurateurs by the National Restaurant Association found that $70 \%$ of their business comes from repeat customers. The same study reported that $52 \%$ of the respondents reported increasing difficulty in maintaining customer loyalty (Sanson, 2004). Thus, return patronage has a significant effect on the long-term success of restaurants. By gaining an understanding of how to provide the highest levels of service, organizations will be able to see increases in both brand loyalty and market share (Oh \& Parks, 1997). The current research examined key elements of organizational culture and the extent to which organizational culture relates to both service quality and customers' intentions to return. 


\section{BACKGROUND}

Traditionally, the restaurant industry is known for being highly bureaucratic in management style and philosophy (Tracey \& Hinkin, 1994). Classical management styles have highly defined, routine practices with strict adherence to specific rules and regulations (Smucker, 2001). They are not concerned with the person or individual doing the job, but rather with identifying the specific tasks and requirements of the job and training employees to perform these duties consistently (Tracey \& Hinkin, 1994). In most cases, the restaurant industry is almost militaristic in nature causing it to be a difficult and demanding industry to those employed within. Industry operators hold beliefs about human relations very similar to those defined by Douglas McGregor (1957) as "Theory X" management style. Theory $\mathrm{X}$ managers view employees as inherently self-centered, passive, lazy, resistant to change, easily misled, and not easily committed to organizational goals (Robbins, Decenzo \& Coulter, 2011). The classical management style works well when there is little competition and local unemployment is high. From a global perspective, competition among restaurant operators is fierce, and the lack of a large labor pool has plagued the restaurant industry for a long time.

According to David Ulrich (1998), human resource (HR) practices must change radically for organizations to optimize their human capital. To transform management style, and hence HR practices, organizations must first understand and manage the complexities of their respective organizational cultures and build stronger levels of commitment (Mattila, 2006; Goodman, Zammuto \& Gifford, 2001).

With limited studies examining these three variables (organizational culture, service quality and behavioral intentions) in the restaurant industry, this study is important to both academics and practitioners. A link has been established between customer loyalty and profitability (Reicheld \& Sasser, 1990). From a practical standpoint, the findings of this research could help restaurateurs build appropriate training programs, including global cultural orientation and service programs to improve relationships between restaurants operators, employees and customers. Improving these relationships should advance levels of sustainability and profitability in restaurants (Kattera et al., 2008; Stevens et al., 1995).

\section{ORGANIZATIONAL CULTURE}

Schein (1990) defines organizational culture as "what a group learns over a period of time as that group solves its problems of survival in an external environment and its problems of internal integration. Such learning is simultaneously a behavioral, cognitive, and an emotional process" (p. 111). Organizational culture is defined by Davidson (2003) as "the shared beliefs and values that are passed on to all within the organization" (p. 206). Due to its labor-intensive nature and the high level of interaction between customers and employees, the hospitality industry has a greater likelihood of being impacted by its employees' actions than many other industries (Kattara, et al., 2008; Davidson, 2003). Therefore, developing an appropriate organizational culture is a critical component in the success of restaurant operations.

Davidson (2003) explored the linkage between organizational climate and service quality in the hotel industry and reported a high correlation between organizational climate and performance. He concludes, "The culture and climate shape not only employee actions but also their commitment to a service ethic. It is this commitment to service that is of paramount importance if customer satisfaction is to be achieved" (p. 211). His model describes organizational culture as the glue between organizational climate, HR practices, and service quality (Davidson, 2003).

A variety of empirically tested organizational culture typologies currently exist. The Competing Values Framework adapted by Cameron and Quinn (1999) was chosen for this study. It delineates four culture types: (1) Clan Culture, (2) Adhocracy Culture, (3) Market Culture, and (4) Hierarchy Culture. Table 1 presents definition and examples of the culture types. 
Table 1.

Organizational Culture Types (Cameron \& Quinn 1999)

\begin{tabular}{|c|c|c|}
\hline Culture Type & Characteristics & Examples \\
\hline Market & $\begin{array}{l}\text { - Goal focused } \\
\text { - Market superiority } \\
\text { - Highly competitive } \\
\text { - Individualized focus }\end{array}$ & - Automobile dealerships \\
\hline Clan & $\begin{array}{l}\text { - Family-type environment } \\
\text { - High level of autonomy } \\
\text { - Focus on human development } \\
\text { - Environment of loyalty \& } \\
\text { commitment } \\
\text { - Team oriented }\end{array}$ & $\begin{array}{l}\text { - Small, independently operated } \\
\text { businesses - ie. "mom \& pop" type } \\
\text { organizations }\end{array}$ \\
\hline Hierarchy & $\begin{array}{l}\text { - Distinct authoritarian structure } \\
\text { - Rules \& regulations } \\
\text { - Distinct lines of communication } \\
\text { - Tight control \& accountability }\end{array}$ & $\begin{array}{l}\text { - Large corporations - IBM, General } \\
\text { Motors Corp, GE }\end{array}$ \\
\hline Adhocracy & $\begin{array}{l}\text { - Breeds entrepreneurship } \\
\text { - Highly dynamic environment } \\
\text { - High levels of creativity }\end{array}$ & $\begin{array}{l}\text { - Many advertising firms } \\
\text { - High-tech software companies }\end{array}$ \\
\hline
\end{tabular}

Research findings on this typology matrix of organizational culture types demonstrate that each culture type is unique in itself and is distinct from the other three culture types. For example, clan culture type and the market culture type have opposite characteristics. Whereas the clan culture type focuses on cohesiveness, teamwork, and human relationship type attributes within an organization, market culture type is a more rigid, goal oriented, highly competitive model that is outwardly focused (Obenchain, 2002). The same is true with the adhocracy culture type and the hierarchy culture type. While the hierarchical culture tends to be very mechanistic in nature and structure, the adhocracy culture type is very organic in structure (Robbins et al., 2011). Empirical research shows that if an organization is characterized as a clan type culture, then it generally is not a market culture. The same would hold true for the hierarchy culture type to the adhocracy culture type (Cameron \& Quinn, 1999; Obenchain, 2002).

There is a great deal of research related to organizational culture in the United States. Still, there continues to be a gap in empirical research on organizational culture types from a global perspective, specifically in the hospitality industry (Doherty, Klenert \& Manfredi, 2007). National cultural influence plays a very important role in the restaurant industry from both the customer perspective as well as the staff. Johns, Henwood and Seaman (2007), in an international study, concluded that service experiences tended to be more dependent on personal value as well as cultural elements.

\section{Clan Focus}

The Competing Values Framework suggests that a clan culture type is most representative of how independent restaurants are structured, very organic in their composition (Robbins et al., 2011; Cameron \& Quinn, 1999). The level of cohesiveness, teamwork, fun and high levels of energy are attributes that draw a "fit" to what restaurants are trying to accomplish from an organizational culture standpoint (Berta, 2002). The ability to build loyalty among customers and build bonded relationships in order to grow business is essential to future success (Bowen \& Shoemaker, 2003). Cameron and Quinn (1999) state that the clan culture type emphasize building customer "partnerships." Many restaurants would seek to establish those types of relationships with customers in order to promote loyalty.

\section{SERVICE QUALITY}

Service firms strive to provide their customers with superior levels of service in order to gain and sustain competitive advantage against industry rivals (Chow \& Luk, 2005). Customer's perceptions of service quality play a vital role in the long-term success of organizations, thereby prompting management on developing sustainable 
programs that will build higher levels of perceived service increasing levels of loyalty ( Hyun, 2010; Meng \& Elliot, 2009). Research has shown that employee behavior has plays a significant role in the delivery of quality service (Chang, 2006; Davidson, 2003; Seidman, 2001).

The intangible nature of the construct of service quality makes it difficult to measure and analyze (Oh \& Parks, 1997; Parasuraman, Zeithalm \& Berry, 1985; Seidman, 2001). In 1985, Parasuraman et al. identified ten quantifiable dimensions of service quality, and later consolidated them into five: (a) Tangibles: facilities, equipment, and appearance of personnel; (b) Reliability: ability to perform the promised service; (c) Responsiveness: willingness to provide the service promptly; (d) Assurance: knowledge and courtesy of employees and their ability to inspire trust and confidence; (e) Empathy: caring, individualized attention the firm provides its customers (Parasuraman et al., 1988). The SERVQUAL instrument was developed to measure service quality based on these five dimensions. It has been validated and tested in a variety of industries including banks, credit card companies, repairs and maintenance firms and long distance telephone companies (Parasuraman et al., 1988, 1991).

In 1995, Stevens, Knutson, and Patton developed DINESERV, a 29-item scale to measure service quality in restaurants. It retained the dimensionality of SERVQUAL and was tested in a multitude of different types of restaurants, ranging from quick service to full service restaurants. The new instrument proved to be valid, and the results concurred with the dimensionality findings of SERVQUAL. The hierarchy of the dimensions as relevant to the customer experience were as follows in order of significance: (1)Reliability; (2)Tangibles; (3)Assurance; (4)Responsiveness; (5)Empathy (Stevens et al., 1995).

\section{BEHAVIORAL INTENTIONS}

Consumers who are dissatisfied with a service experience may take a variety of different actions. They can voice their opinion to management, they can say nothing and just not return to that organization, or they can continue patronizing the organization and not say anything (Susskind, 2002). Research demonstrates that a dissatisfied customer could tell an average of 10-20 other people (Brown, 1997; Shaw-Ching Liu, Furrer \& Sudharshan, 2001; Tax, Brown \& Chandrashekaren, 1996). Ultimately, the economic impact of customer retention is incredibly significant for profitability. The defining study conducted by Reichheld and Sasser (1990) showed that a 5\% increase in customer retention equates to a net present value increase of $25-125 \%$ in profitability (Bowen \& Chen, 2001; Reicheld \& Sasser, 1990; Shaw-Ching Liu et al., 2001). From a restaurateur's perspective, if the organization were to increase its guest return rate from $76 \%$ to $81 \%$, profits would more than likely double (Stevens et al., 1995).

In 1996, Zeithaml et al. showed that behavioral intentions are intervening variables between service quality and financial gain or loss of an organization. Their research postulated that a positive level of service quality creates favorable behavioral intentions. This, in turn, increases the probability that customers' relationship to the organization will be strengthened and that they will be repeat customers. Conversely, low levels of service quality will create unfavorable behavioral intentions, which in turn could cause patrons not return to the business (Alexandris, Dimitriadis \& Markata, 2002; Zeithaml et al., 1996).

Zeithaml et al. (1996) developed the Behavioral Intentions Battery to measure customers' intentions to defect or return. Their final framework included five dimensions (Bloemer et al., 1999): (1) loyalty to company, (2) propensity to switch, (3) willingness to pay more, (4) external response to a problem, and (5) internal response to a problem (Alexandris et al., 2002; Bloemer et al., 1999; Zeithalm et al., 1996). Although some variations of the dimensions have been found across studies, the overall reliability and validity of Zeithaml et al.'s (1996) scale is supported. The theoretical model itself was supported in all subsequent studies since its formulation in 1996 both in studies conducted in the United States and abroad (Meng \& Elliot, 2009; Alexandris et al., 2002; Athanassopoulos et al., 2001; Baker \& Crompton, 2000; Bloemer et al., 1999; Shaw-Ching Liu et al., 2001; Zeithaml \& Bitner, 2000).

\section{HYPOTHESES}

With limited research conducted in the restaurant industry using the three variables identified in this study, the findings can be of great value to both hospitality industry practitioners and academia. The motivation for this 
research from a practical standpoint, is to help restaurateurs build appropriate programs, including cultural orientation and service programs to improve relationships between the restaurants, employees and customers. The restaurant industry is dependent on multi-cultural employees. Therefore, the ability of management to understand the national culture implications are also critical factors in building successful organizational cultures (Johns et al., 2007).

The current study investigated the relationship between two types of organizational culture, clan culture and market culture as defined by Cameron and Quinn (1999), service quality as defined by Parasurraman, et al. (1985, 1988, 1991); Bojanic and Rosen (1994); Stevens, et al. (1995) and behavioral intentions as defined by Zeithalm, et al. (1996); and Alexandris et al. (2002). There is some research in the hospitality industry on service quality and behavioral intentions in the international arena, but it is limited with regard to how organizational culture relates to service quality and behavioral intentions (Qin, Prybutok \& Zhao, 2010; Qin \& Prybutok, 2008). Cameron and Quinn (1999) report that customers play an integral role in developing a clan culture, as it invites them to become part of the "family," and associated with the internal environment of the organization. The market type culture relates to the external environment of organizations in terms of dominating other organizations and competing with them to sell products or services; Cameron and Quinn (1999) position it as the polar opposite of clan culture. Therefore, the first and third hypotheses propose that clan culture is positively related to service quality and intent to return, while the second and fourth propose that market culture is negatively related to the outcomes in the independently owned, casual dining restaurant industry. Figure 1 depicts these relationships.

$\mathbf{H}_{1}$ : $\quad$ Clan culture type is positively related to service quality in the independently owned, casual dining restaurant industry.

$\mathbf{H}_{2}$ : $\quad$ Market culture type is negatively related to service quality in the independently owned, casual dining restaurant industry.

$\mathbf{H}_{3}$ : Clan type culture is positively related to customers' intentions to return in the independently owned, casual dining restaurant industry.

$\mathbf{H}_{4}$ : Market type culture is negatively related to customers' intentions to return in the independently owned, casual dining restaurant industry.

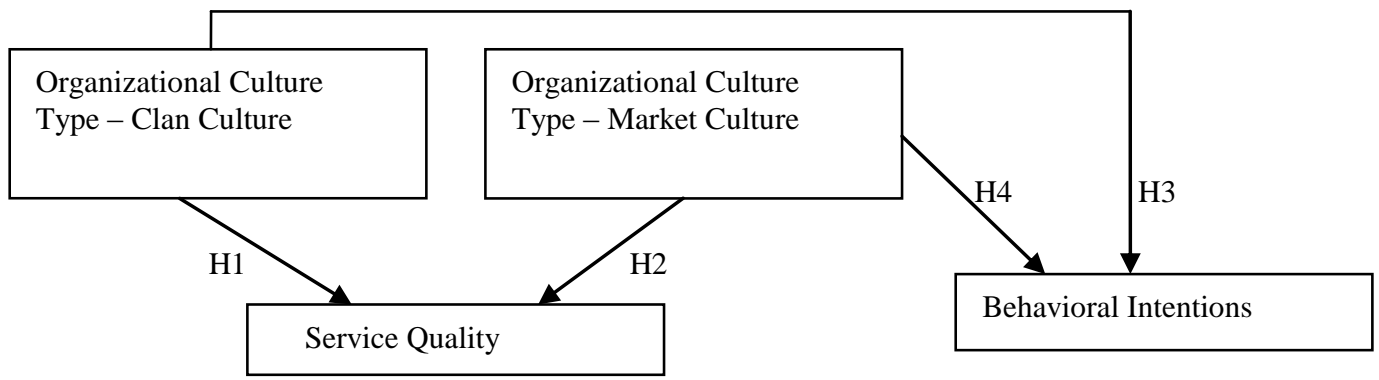

Figure 1: Theoretical Model Examined

\section{METHODOLOGY}

\section{Study Sample}

Customers in six independently owned and operated restaurants (U.S.) participated in this study as this population tends to be more organic in structure and lends itself better to the initial study of the clan type dimensions versus the more mechanistic structured, national chain restaurants (Robbins et al., 2011). A total of 310 questionnaires were distributed to customers dining in the participating restaurants. The surveys were distributed to every 10 th customer over the age of 18 dining in the restaurants. Additionally, the customers participating in the 
study had to have dined in the restaurant at least once before in order to be eligible for the study. Of the 310 surveys distributed, 17 were incomplete and not included in the final sample of 293 responses.

\section{Survey Instrument}

The research instrument for the study included DINESERV (Stevens et al., 1995) reliability of .89 and greater (29 items); the Behavioral Intentions Battery (Zeithalm et al., 1996), reliability of .70 and greater (13 items); and the organizational culture type scale ( 3 items for two culture types) developed by Yeung, Brockbank and Ulrich (1991), reliability of .76 and greater. The 3-item scale clan culture type yielded a Cronbach's alpha reliability of .81, which is higher than that reported in two previous studies reported in Table 2 . The reliabilities estimates in this study yielded slightly higher scores than the ones reported above except for the market culture scale. The 3-item scale yielded a Cronbach's alpha reliability of .62. An inter-item correlation analysis indicated that one item correlated only .178, and it was deleted. The revised 2-item scale yielded an acceptable reliability of .73.

Table 2: Reliabilities (coefficient alpha) for clan and market culture type scales

\begin{tabular}{|l|c|c|c|}
\hline \multicolumn{1}{|c|}{ Culture Type } & Obenchain (2002) & Yeung, Brockbank \& Ulrich (1991) & Current study \\
\hline Clan & .73 & .79 & .81 \\
\hline Market & .79 & .77 & .73 \\
\hline
\end{tabular}

\section{RESULTS AND DISCUSSION}

\section{Demographics of Respondents}

Key sample demographic data include gender, ethnicity and age of the respondents. Respondents were $50.9 \%$ men, $49.1 \%$ women. The largest ethnic group was white $(88.9 \%)$. The largest single age category was that of 50-59 years of age with $27.7 \%$ of the sample in that category. Two other age categories were slightly lower in percentage; the $40-49$ year category represented $22.1 \%$ of the sample and the 60 and over category, $21.5 \%$. Thus, $71 \%$ of the respondents were 40 years old and above.

Additional questions asked of the respondents include the reason for dining, number of times the respondents dine out per month and the amount of money they spend per person when dining out (in US dollars). Results show that $58.6 \%$ of the respondents dine out for pleasure, $36.6 \%$ dine out for business and $4.8 \%$ of respondents recorded an answer of other. In addition, $48.4 \%$ of the respondents dine out more than six times per month. The dollar amount per person per visit, by percentage is $39.4 \%$ at $\$ 15-\$ 20$ (US) and $38.4 \%$ at $\$ 20-\$ 30$ (US).

\section{RESULTS}

Table 3 shows the means, standard deviations, correlations, and reliabilities for the study variables. The reliabilities (Cronbach's alpha) are all above 0.70 . The correlations are in the expected directions except that market culture type is positively related both to service quality $(\mathrm{r}=0.28, \mathrm{p}<.001)$ and to behavioral intention $(\mathrm{r}=.13, \mathrm{p}<.05)$ and not negatively related as expected. However, the regression results presented next provide a more rigorous test of the relationship because it takes into account the influence of the other independent variable (either clan or market type culture in this study. Correlation analysis shows a high positive correlation between the clan culture type and service quality, which concurs with the previous studies conducted in the hotel sector of the hospitality industry. Kattara et al., (2008) and Davidson (2003) reported a positive correlation between organizational climate and employee behavior with regard to service quality in the hotel industry. There is a strong positive correlation between clan culture and behavioral intention $(\mathrm{r}=0.50, \mathrm{p}<.001)$, as expected.

The strong positive correlation for service quality and behavioral intentions $(\mathrm{r}=0.62, \mathrm{p}<.001)$ for the casual dining restaurant setting in this study are consistent with previous research in various industries which reported a strong positive relationship between perceptions of service quality and customers' intentions to return (Meng \& Elliot, 2009; Alexandris et al., 2002; Athanassopoulos et al., 2001; Baker \& Crompton, 2000; Shaw-Ching Liu et al., 2001). 
Table 3: Means, Standard Deviations, Correlations, and Reliabilities

\begin{tabular}{|l|c|c|c|c|c|c|}
\hline & Mean & $\begin{array}{c}\text { Standard } \\
\text { Deviation }\end{array}$ & Clan & Market & $\begin{array}{c}\text { Service } \\
\text { Quality }\end{array}$ & $\begin{array}{c}\text { Behavioral } \\
\text { Intentions }\end{array}$ \\
\hline Clan & 5.67 & 1.03 & $(.81)$ & & & \\
\hline Market & 4.99 & 1.36 & $.44^{* * *}$ & $(.73)$ & & \\
\hline Service Quality & 6.22 & .59 & $.56^{* * *}$ & $.28^{* * *}$ & $(.95)$ & \\
\hline Behavioral Intentions & 5.56 & .74 & $.50^{* * *}$ & $.13^{*}$ & $.62^{* *}$ & $(.79)$ \\
\hline
\end{tabular}

$\mathrm{N}=293$. Figures in parentheses on the diagonal indicate Cronbach's alpha reliability for the variables.

* correlation is significant at the 0.05 level.

*** correlation is significant at the 0.001 level.

Table 4 presents the results of regressing service quality on clan culture type and market culture type. The $\mathrm{F}$ of $56(\mathrm{p}<.001)$ indicates that this portion of the study model is highly significant and represents a good approximation of the activities in the model. Clan culture type is strongly, positively correlated with service quality and market culture is not related to service quality. The regression results provide support for Hypothesis 1 concerning a positive relationship between clan culture and service quality; they do not support Hypothesis 2 that proposed a negative relationship between market culture and service quality as there is no relationship between them.

Table 4: Regression Results, Service Quality Dependent

\begin{tabular}{|l|c|c|c|c|c|c|}
\hline \multicolumn{1}{c|}{$\begin{array}{c}\text { Independent } \\
\text { Variables }\end{array}$} & $\mathbf{B}$ & $\mathbf{R}^{\mathbf{2}}$ & $\mathbf{S E}$ & $\mathbf{F}$ & $\mathbf{d f}$ & Sig \\
\hline Clan Culture & 4.35 & .315 & .167 & $68.8 * * *$ & 2,290 & .000 \\
\hline Market Culture & .316 & & .031 & & & .000 \\
\hline
\end{tabular}

Table 5 presents the results of regressing intention to return on clan and market type culture. The $\mathrm{F}$ of 56 $(\mathrm{p}<.001)$ indicates that the model is significant. The regression coefficient associated with clan culture indicates a strong positive relationship with behavioral intention, thus supporting Hypothesis 3. Market culture relates negatively to behavioral intention, thus supporting Hypothesis 4. Table 5 results, then, show that clan (family-type) culture relates positively to intention to return to the restaurant so it helps generate repeat customers. Market culture type, the opposite of clan culture, focuses on beating competitors, relates negatively to intention to return.

Table 5: Regression Results, Intention to Return Dependent

\begin{tabular}{|l|c|c|c|c|c|c|}
\hline $\begin{array}{c}\text { Independent } \\
\text { Variables }\end{array}$ & $\mathbf{B}$ & $\mathbf{R}^{2}$ & $\mathbf{S E}$ & $\mathbf{F}$ & $\mathbf{d f}$ & Sig \\
\hline & $\mathbf{3 . 8 1}$ & .297 & .221 & $\mathbf{5 6 . 0} * * *$ & $\mathbf{2 , 2 9 0}$ & $\mathbf{. 0 0 0}$ \\
\hline Clan Culture &. $\mathbf{4 0 0}$ & & .038 & & & .000 \\
\hline Market Culture & $\mathbf{. 1 1 2}$ & & .032 & & & .001 \\
\hline
\end{tabular}

Taken together, the above findings support the proposition that customers' perceptions of organizational culture affect both service quality and behavioral intentions in restaurants as in other sectors of the hospitality industry as well as other industries (Meng \& Elliot, 2009; Kattara et al., 2008; Davidson 2003; Alexandris et al., 2002). Clan culture type, as expected, relates positively to service quality and to intention to return to the restaurant. Its implications will be discussed more fully below. Market culture, the polar opposite of clan culture focused as it is on external competitors, is not positively related to either service quality or intention to return.

\section{CONCLUSIONS AND MANAGERIAL IMPLICATIONS}

The above findings provide empirical evidence that clan culture type relates positively to both service quality and behavioral intention in the independent, casual dining restaurant industry. Market culture, on the other 
hand, is not related to service quality and relates negatively to intention to return. The regression results tested the hypotheses because they can tell us if a given independent variable (e.g., market culture) relates to the outcome (customer service in the first regression and behavioral intention in the second) given the presence of the other independent variable(s), in this case, clan culture. A correlation coefficient tells if two variables are correlated in the direction (positive or negative) of the relationship, but it does take into account other factors that may affect the relationship. Therefore, there may appear to be discrepancies between the regression and correlation results reported above. Another contributing factor in the above results is the relatively weak psychometric properties of the market type culture scale, which is discussed more fully below in the section on limitations.

This study extended the literature of organizational culture as it relates to the restaurant industry. The findings have important ramifications for practitioners in the casual dining restaurant industry. According to Cameron and Quinn (1999), the characteristics of a clan culture type include an environment of loyalty, commitment, and participation, where a sense of belonging and family form the essence and foundation of the organization. The restaurants in this study showed a significantly high level of service quality (mean of 6.22 on a 7 point scale), with a dominant clan culture evident (mean of 5.62 on a 7 point scale). Practitioners might want to consider developing an organizational culture that captures the elements of the clan culture in order to improve service delivery systems and help reduce factors that negatively influence service delivery. The study also suggests that having good service programs in place and improving service levels will increase repeat business in this particular sector of the restaurant industry. Previous studies revealed that customers in all segments of the restaurant industry have high expectation levels when it comes to service (Meng \& Elliot, 2009; Stevens et al., 1995). Meeting and exceeding those expectations is of paramount importance to restaurateurs if they want to increase the frequency of repeat customers.

The bankruptcy figures suggest that being a successful owner of any small business is extremely challenging. Foodservice operation failure rates indicate that the challenges involved in running restaurants are far greater than many other businesses (Parsa \& Self, 2005). The restaurant industry is a unique and complex business, needing expertise in many areas, from production to service orientation (Wyckoff, 2001). Restaurateurs need to be concerned with both product quality and service quality (Alonso \& O'Neill, 2010; Bojanic \& Rosen, 1994). In the service industry, service quality and customers' intentions to return are of paramount importance for organizational success. Many variables affect the service delivery process and the likelihood of error is extremely great.

The primacy of good service delivery in this industry results from the high level of employee interaction with the customers. For example, a customer may be completely satisfied with the food they ordered, but not satisfied with their overall dining experience. Customer perception of poor service from the server may lead to negative behavioral consequences leading to loss of return customers.

With the complex nature of the restaurant industry, it is our hope that the study findings can benefit independent or family owned restaurants. Human interactions play a significant role in this industry, from both customer and employee perspectives. The goal is for employees to become a strategic, core competency, where they embody a key strategic resource. Additionally, research has shown that hospitality organizations that have selfmanaged teams and empowerment strategies have lower employee turnover and higher levels of success and profitability (Crook, Ketchen, \& Snow, 2003). In order to build repeat business, restaurateurs need to be able to develop the appropriate culture, build proper service programs, and successfully execute these tasks simultaneously. The findings of this study can also function as a starting point to help restaurateurs develop these systems.

\section{LIMITATIONS AND FUTURE RESEARCH}

The fact that the study was conducted in the United States was a limitation to the study on a global scale. Studies have shown that the perception of service quality, with respect to the service encounter itself, varies with respect to national culture (Johns, Henwood \& Seaman, 2007). Therefore, a replication of this study in countries with different cultural dimensionality may result in different findings.

Another limitation is the inadequacy of the market culture scale in this study; it needs revisions for the restaurant and the entire hospitality industry. It's extremely low reliability estimate was unexpected because 
previous research yielded adequate reliability estimates. The two outcomes are unique in the research literature on the use of the scales. Superficially, the three items for each of the two measures (listed at the beginning of the appendix) appear to measure different ideas. However, the market scale items describe being achievement oriented, being concerned with getting the job done, and accomplishing goals may, in diners' perceptions, be similar to the clan culture concepts of loyalty to the organization and employees sharing a lot of themselves to provide quality service.

Recommendations for future research on organizational culture within the hospitality industry include developing a new set of items for market culture; they should include concepts concerning competitiveness with other organizations in the same industry and then be examined in models similar to the one tested here. Another possibility is that market culture type may not be part of the diners' frame of reference in this setting and in similar ones. Yet, in the fast-food segment of the hospitality industry, competitiveness may be a factor in customers' intention to return to the restaurant. However, the market culture type does include highly competitive forces (Cameron \& Quinn, 1999) and that could create negative attributes for diners in the independently owned, casual dining restaurant industry.

In conclusion, this study contributed to research in the independently owned, casual dining restaurant environment by creating and testing the influence of two types of organizational cultures as they relate to customer service and intention to return. The influence of the family-oriented type of culture is positively related to customer service and to intention to return.

\section{AUTHOR INFORMATION}

Dean A. Koutroumanis, is an assistant professor of management at the John H. Sykes College of Business at the University of Tampa. Research interests include entrepreneurship, family business and organizational behavior. He has published in the areas of organizational culture, commitment and strategy. He additionally has an extensive background in the restaurant industry as a practitioner in a family operated business. E-mail: dkoutroumanis@ut.edu. Corresponding author.

Mary Anne Watson, is a professor of management at the John H. Sykes College of Business at the University of Tampa. Research interests include emotional intelligence, leadership and service learning. Most recently she has published in the areas of case research and service learning. E-mail: mawatson@ut.edu

Barbara R. Dastoor, is a professor of organizational behavior at the H. Wayne Huizenga School of Business and Entrepreneurship at Nova Southeastern University. Research interests include cross-cultural human resources and organizational behavior. She has published in the areas of leadership, organizational commitment and culture. E-mail: dastoor@nsu.nova.edu

\section{REFERENCES}

1. Alonso, A.D., O’Neill, M.A. (2010). "Consumers' Ideal Eating Out Experience as it Refers to Restaurant Style: A Case Study," Journal of Retail and Leisure Property, 9(4), 263.

2. Alexandris, K., Dimitriadis, N., and Markata, D. (2002). "Can Perception of Service Quality Predict Behavioral Intentions? An Exploratory Study in the Hotel Sector in Greece," Managing Service Quality, Bedford, 12(4), 224.

3. Athanassopoulos, A., Gounaris, S., and Stathakopoulos, V. (2001). "Behavioural Responses to Customer Satisfaction: An Empirical Study," European Journal of Marketing, 35(5/6), 687-707.

4. Baker, D., and Crompton, J. (2000). "Quality, Satisfaction and Behavioral Intentions," Annals of Tourism Research, 27, 785-804.

5. Berta, D. (2002). "Sexual Harassment Remains Nagging Issue for Food Service Industry," Nations Restaurant News, 36(50), 1, 16.

6. Bloemer, J., deRuyter, K., and Wetzels, M. (1999). "Linking Perceived Service Quality and Service Loyalty: A Multi-Dimensional Perspective," Journal of Marketing, 33, 1082-1106. 
7. Bojanic, D. C., and Rosen, L. D. (1994). "Measuring Service Quality in Restaurants: An Application of the SERVQUAL Instrument," Hospitality Research Journal, 18(1), 3-14.

8. Bowen, J. T., and Shoemaker, S. (1998). "Loyalty: A Strategic Commitment," Cornell Hotel and Restaurant Administration Quarterly, 39(1), 12-25.

9. Brandau, M. (2009) "Restaurants reap the rewards of loyalty initiatives." Nation's Restaurant News, 43, (22), 1-3.

10. Brown, S. (1997). "Service Recovery Through Information Technology: Complaint Handling Will Differentiate Firms in the Future," Marketing Management, 6(3), 25-27.

11. Cameron, K. S., and Quinn, R. E. (1999). Diagnosing and changing organizational culture based on competing values framework. Reading, MA: Addison Wesley.

12. Chang, C. P. (2006). "A Multilevel Exploration of Factors Influencing the Front-Line Employees' Service Quality in International Tourist Hotels," Journal of American Academy of Business, 9(2), 285-294.

13. Chow, C. C. and Luk, P. (2005). "A Strategic Service Quality Approach Using Analytic Hierarchy Process," Managing Service Quality, 15(3), 278-290.

14. Crook, T. R., Ketchen, D. J., and Snow, C. C. (2003). "Competitive Edge: A Strategic Management Model," Cornell Hotel and Restaurant Administration Quarterly, 44(3), 44-53.

15. Collins, A.B. (2007). "Human Resources: A Hidden Advantage?," International Journal of Contemporary Hospitality Management, 19(1), 78-84.

16. Davidson, M. C. (2003). "Does Organizational Climate Add to Service Quality in Hotels?," International Journal of Contemporary Hospitality Management, 15(4), 206-213.

17. Goodman, E. A., Zammuto, R. F., and Gifford, B. D. (2001). "The Competing Values Framework: Understanding the Impact of Organizational Culture on the Quality of Work Life," Organizational Development Journal, 19(3), 58-68.

18. Hyun, S.S. (2010). "Predictors of Relationship Quality and Loyalty in the Chain Restaurant Industry", Cornell Hospitality Quarterly, 51(2). 251.

19. Johns, N., Henwood, J. and Seaman, C. (2007). "Culture and Service Predisposition Among Hospitality Students in Switzerland and Scotland", International Journal of Contemporary Hospitality Management, 19(2), 146-158.

20. Kattara, H.S., Weheba, D. and El-Said, O.A. (2008) “The Impact of Employee Behaviour on Customers' Service Quality Perceptions and Overall Satisfaction", Tourism and Hospitality Research, 8(4), 309-323.

21. Lokyer, S.E. (2009) “Closures, downbeat industry reports deflate recent turnaround optimism.” Nation's Restaurant News, 43(29), 4-6.

22. Mattila, A.S. (2006). "How Affective Commitment Boosts Guest Loyalty (and Promotes Frequent Guest Programs)," Cornell Hotel and Restaurant Administration Quarterly, 47(2), 174-181.

23. Meng, J. and Elliot, K. (2009) "Investigating Structural Relationships Between Service Quality, Switching Costs, and Customer Satisfaction”, Journal of Applied Business and Economics, 9(2), 54-67.

24. National Restaurant Association (2010). “2010 Outlook.” http://www.restaurant.org. Accessed on Jan. 9, 2010.

25. Oh, H., and Parks, S. (1997). "Customer Satisfaction and Service Quality: A Critical Review of the Literature and Research Implications for the Hospitality Industry,” Hospitality Research Journal, 20(3), 3664.

26. Parasuraman, A., Berry, L. L., and Zeithalm, V. A. (1991a). "Refinement and Reassessment of the SERVQUAL Scale," Journal of Retailing, 67(4), 420-450.

27. Parasuraman, A., Berry, L. L., and Zeithalm, V. A. (1991b). "Understanding Customer Expectations of Service," Sloan Management Review, 32, 39-48.

28. Parasuraman, A., Zeithalm, V. A., and Berry, L. L. (1985). "A Conceptual Model of Service Quality and its Implications for Further Research," Journal of Marketing, 49, 41-50.

29. Parasuraman, A., Zeithalm, V. A., and Berry, L. L. (1988). "SERVQUAL: A Multiple Item Scale for Measuring Consumer Perceptions of Service Quality," Journal of Retailing, 64(1), 12-40.

30. Parsa, H.G. and Self, J.T. (2005). "Why Restaurants Fail", Cornell Hospitality Quarterly, 46(3), 304-322.

31. Qin, H. and Prybutok, V.R. (2008). "Determinants of Customer-Perceived Service Quality in Fast-Food Restaurants and Their Relationship to Customer Satisfaction and Behavioral Intentions," The Quality Management Journal, 15(2), 35-51. 
32. Qin, H., Prybutok, V.R. and Zhao, Q. (2010). "Perceived Service Quality in Fast Food Restaurants:

Empirical Evidence from China", The International Journal of Quality and Reliability Management, 27(4), 424.

33. Reicheld, F., and Sasser, W. E. (1990). “Zero Defections: Quality Comes to Services," Harvard Business Review, 68, 105-111.

34. Robbins, S. P., Decenzo, D. A., Coulter, M. (2011). Fundamentals of Management: Essential Concepts and Applications (7 ed., Rev.). Upper Saddle River, NJ.: Pearson Prentice Hall.

35. Sanson, M. (2004). "Revved and Ready," Restaurant Hospitality, 88(2), 41-49.

36. Schein, E. (1990). "Organizational Culture," American Psychologist, 45(2), 109-119.

37. Schneider, B., and Bowen, D. E. (1993). "The Service Organization: Human Resources Management is Crucial," Organizational Dynamics, Spring, 39-52.

38. Seidman, A. (2001). "An Investigation of Employee Behavior on Customer Satisfaction in the Quick Service Restaurant Industry," D.B.A. dissertation, Nova Southeastern University.

39. Shaw-Ching Liu, B., Furrer, O., and Sudharshan, D. (2001). "The Relationship Between Culture and Behavioral Intentions Toward Services," Journal of Service Research, 4(2), 118-130.

40. Smucker, J. (2001). "Employee Empowerment and Self-direction in a Family Dining Restaurant Chain: A Case Study," Ph.D. dissertation, Walden University.

41. Stamper, C. L., and Van Dyne, L. (2003). "Organizational Citizenship: A Comparison Between part- time and Full-time Service Employees," Cornell Hotel and Restaurant Administration Quarterly, 44(1), 33-43.

42. Stevens, P., Knutson, B., and Patton, M. (1995). "DINESERV: A Tool for Measuring Service Quality," Cornell Hotel and Restaurant Administration Quarterly, 36(2), 56.

43. Susskind, A. M. (2002). "I Told You So!: Restaurant Customers' Word-of-Mouth Communication Patterns," Cornell Hotel and Restaurant Administration Quarterly, 43(2), 75-85.

44. Tax, S., Brown, S., and Chandrashekaren, M. (1996). "Customer Evaluations of Service Complaint experiences: Implications for Relationship Marketing,” Working paper: Center for Service Marketing and Management. College of Business, Arizona State University, Tempe.

45. Tracey, J. B., and Hinkin, T. R. (1994). "Transformational Leaders in the Hospitality Industry," Cornell Hotel and Restaurant Administration Quarterly, 35(2), 18-25.

46. Urlich, D. (1998). “A New Mandate for Human Resources," Harvard Business Review, 76(1), $125-134$.

47. Wyckoff, D. D. (2001). "New Tools for Achieving Service Quality," Cornell Hotel and Restaurant Administration Quarterly, 42(4) 25-38.

48. Yeung, A., Brockbank, J., and Ulrich, D. (1991). "Organizational Culture and Human Resource Practices: An Empirical Assessment," in Research in Organizational Change and Development. Ed. R.W. Woodman and W.A. Pasmore. London.: JAI Press, pp. 59-82.

49. Zeithalm, V. A., and Bitner, M. J. (2000). Services Marketing: Integrating Customer Focus Across the Firm. NY.: McGraw - Hill.

50. Zeithalm, V. A., Berry, L. L., and Parasuraman, A. (1996). "The Behavioral Consequences of Service Quality," Journal of Marketing, 60, 31-46. 


\section{NOTES}

